Ambiente \& Água - An Interdisciplinary Journal of Applied Science
ISSN 1980-993X - doi:10.4136/1980-993X
www.ambi-agua.net
E-mail: ambi.agua@gmail.com

\title{
Scaling of ammonia stripping towers in the treatment of groundwater polluted by municipal solid waste landfill leachate: study of the causes of scaling and its effects on stripping performance
}

doi: 10.4136/ambi-agua.1567

Received: 20 Nov. 2014; Accepted: 25 Dec. 2014

\author{
Paolo Viotti ${ }^{*}$; Renato Gavasci \\ ${ }^{1}$ University of Rome "La Sapienza", Rome, Italy \\ Department of Civil, Buildings and Environmental Engineering \\ ${ }^{2}$ University of Rome "Tor Vergata", Rome, Italy \\ Department of Civil Engineering and Computer Science Engineering \\ "Corresponding author: e-mail: paolo.viotti@uniroma1.it, \\ gavasci@ing.uniroma2.it
}

\begin{abstract}
This paper documents the causes of the scaling of stripping towers used for the treatment of groundwater polluted by the leachate from an old municipal solid waste (MSW) landfill in northern Italy. The effects of the scaling on the stripping performance are also reported. The whole process consists of a coagulation-flocculation pre-treatment at $\mathrm{pH}>11$, followed by an ammonia stripping stage, after heating the water to $38^{\circ} \mathrm{C}$ in order to improve removal efficiency. The stripped ammonia is recovered by absorption with sulfuric acid, producing a $30 \%$ solution of ammonium sulfate (reused as a base fertilizer). The effluent air stream is recirculated to the stripping towers (closed loop systems) in order to avoid an excessive temperature drop inside the packings, mainly in winter, with consequent loss of efficiency and risk of icing. The progressive scaling of the packing has resulted in a loss of ammonia removal efficiency from an initial value of $98 \%$ (clean packing) down to $80 \%$ after six months of continuous operation, necessitating a chemical cleaning. Optimum conditions for design and operation of the stripping process are also documented.
\end{abstract}

Keywords: ammonia stripping, aquifer reclamation, landfill leachate, packing.

\section{Incrustação das torres de arraste de amônia no tratamento de águas subterrâneas poluídas pelo chorume de aterro de resíduos sólidos urbanos: estudo das causas da incrustação e seus efeitos na eficiência de extração}

\section{RESUMO}

O artigo relata as causas de incrustação nos materiais de enchimento das torres de arraste no tratamento de águas subterrâneas poluídas pelo chorume de um antigo aterro de resíduos sólidos urbanos no norte da Itália. Também relata os efeitos da incrustação sobre a eficiência de extração de amoníaco. O processo de tratamento é constituído numa primeira etapa de coagulação-floculação a $\mathrm{pH}>11$ e subsequente remoção da amônia em torres de arraste após 
o aquecimento das águas residuais a $38^{\circ} \mathrm{C}$ para melhorar a eficiência da remoção. A amônia foi recuperada por absorção com o ácido sulfúrico, com a produção de uma solução a 30\% de sulfato de amônia reutilizado como fertilizante de base. O fluxo de ar que sai das colunas de absorção é recirculado nas torres de arraste (circuito fechado de recirculação do ar) para evitar quedas excessivas de temperatura no interior das torres, sobretudo no inverno, resultando em perda de eficácia e risco de formação de gelo. A incrustação progressiva do enchimento das torres resultou em uma perda de eficiência de remoção de amoníaco a partir do valor inicial de $98 \%$ (enchimento limpo) até $80 \%$ depois de seis meses de funcionamento contínuo, necessitando de lavagem química. $\mathrm{O}$ artigo também documenta as condições ótimas para o projeto e a operação do processo de extração de amoníaco.

Palavras-chave: extração de amoníaco, incrustação calcária, lixiviados de aterro sanitário, recuperação de aquífero.

\section{INTRODUCTION}

Scientific literature documents many cases of groundwater pollution due to the leachate generated by landfills of municipal solid waste (MSW) and similar waste (Raboni et al., 2015; Rada et al., 2014b; Regadío et al., 2012; Torretta et al., 2014). The quality of the leachate is mainly characterized by the relevant presence of ammonia, organic compounds and heavy metals. Leachate treatment can be performed with various biological and physical-chemical processes and a combination of different techniques is required due to the complex quality of the wastewater. One of the major problems of such treatments is the removal of the very high concentrations of ammonia which remain rather stable throughout the life of the landfill. As is known, biological processes are widely used in the treatment of wastewaters with medium-low ammonia concentrations. The most typical applications are in sewage treatment (Eramo et al., 1994; Farabegoli et al., 2003; Raboni et al., 2014a; 2013a; 2014b; 2014c; Renou et al., 2008; Sun et al., 2012; Torretta et al., 2013b), but several applications to leachate treatment are known (Torretta et al., 2013a). Great interest is currently directed to biological processes for the treatment of waste air streams contaminated by ammonia and other volatile compounds (Copelli et al., 2012; Rada et al., 2014a; Torretta et al., 2013a).

There are several physical-chemical processes for ammonia removal from leachate, including air stripping, precipitation as magnesium ammonium phosphate (struvite), photochemical and electrochemical processes, ion-exchange, membrane processes, chemical oxidation and adsorption. However, most such treatments are still at an experimental level. A special mention should be made of the stripping process, due to its numerous applications for the removal of ammonia as well as other volatile compounds. In several cases, the stripping process has been considered the optimal solution to achieve a high removal efficiency together with ammonia recovery by a subsequent chemical absorption (Campos et al., 2013; Ferraz et al., 2013; Yilmaz et al., 2010).

MSW landfill leachate is also characterized by a significant presence of hardness. This presence, associated with high alkalinity can easily lead to scaling in the ammonia stripping processes. Scaling results in a reduction of the efficiency of the stripping process, requiring complex washing operations with acidic solutions. This paper specifically studies the scaling phenomenon and its effects on ammonia removal efficiency.

\section{MATERIALS AND METHODS}

\subsection{The treatment plant}

Figure 1 shows the simplified diagram of the physical-chemical process for the treatment of polluted groundwater (Raboni et al., 2013b). The plant is composed of two parallel lines. 
Highly contaminated groundwater $\left(Q=160 \mathrm{~m}^{3} \mathrm{~h}^{-1}\right)$ is first treated by coagulation-flocculation, dosing $41 \%$ and $35 \%$ solutions of ferric chloride and sodium hydroxide, respectively ( $\mathrm{pH}$ increase up to $\mathrm{pH}>11$, converting the ammonium ions into free ammonia in order to aid the subsequent stripping process). The effluent of the coagulation-flocculation step is heated to a temperature of $38^{\circ} \mathrm{C}$ (by means of the landfill biogas) in order to improve the efficiency of ammonia stripping. This pre-heating was determined by the need to achieve highly efficient ammonia removal in order to comply with the standards for the final discharge into the nearby waterway. The stripping air (flow rate $120,000 \mathrm{Nm}^{3} \mathrm{~h}^{-1}$ for each line) flows through the towers in countercurrent to the water.

The two stripping towers (one tower per line) are made of concrete with an inner lining in polypropylene and have an internal diameter of $5.5 \mathrm{~m}$ and a $12 \mathrm{~m}$ packing height (Pall rings), divided into two consecutive stages to avoid excessive loads on the rings and to prevent crushing.

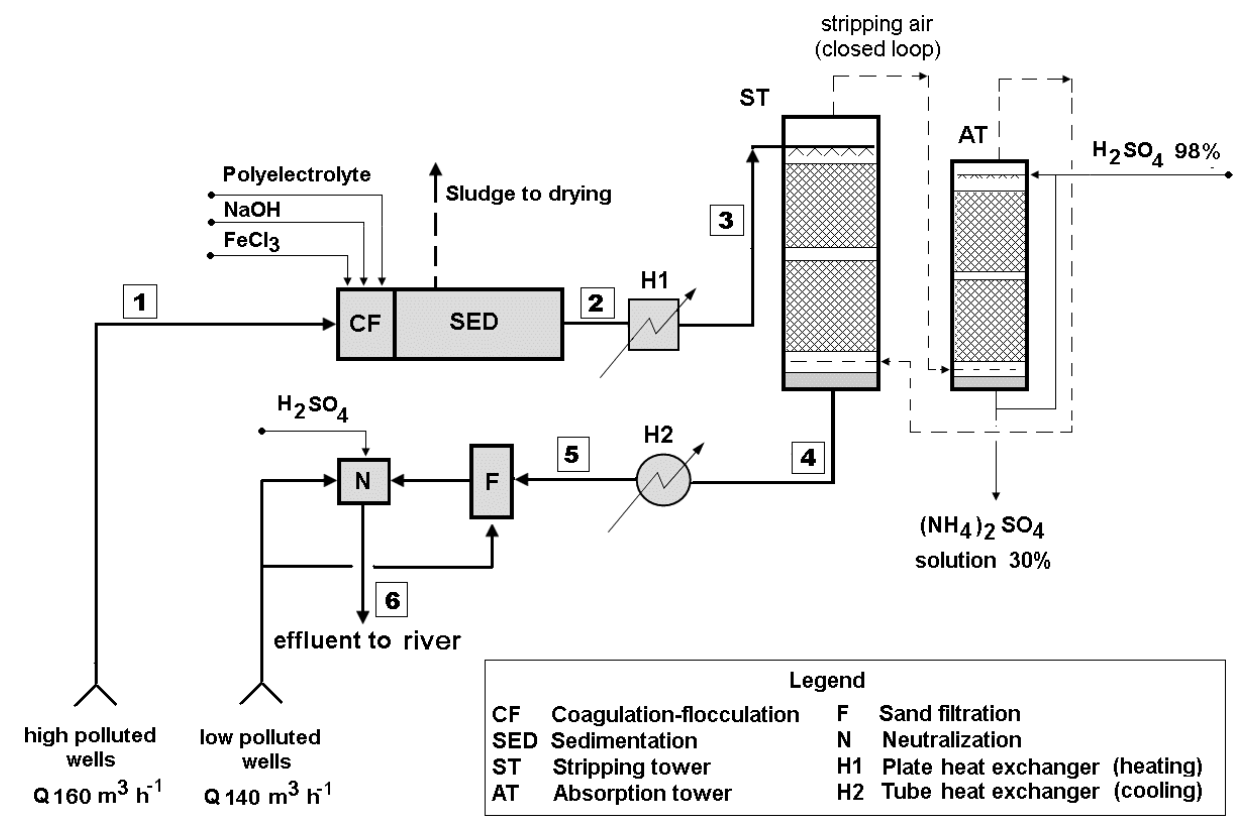

Figure 1. Diagram of the physical-chemical process for the treatment of polluted groundwater.

All of the plant's operating conditions (e.g. water temperature; hydraulic load; stripping air flow rate) and construction features (e.g. packing height; type of packing) were defined by preliminary tests carried out on a small pilot plant.

The outgoing air from the stripping towers, enriched with ammonia, feeds the absorption towers (two towers per line), which are made of polypropylene, with an internal diameter of $3.6 \mathrm{~m}$ and a $9 \mathrm{~m}$ packing height. A countercurrent recirculating absorbent solution of sulfuric acid is fed to the towers. The bottom flow of the absorption towers consists of a $30 \%$ ammonium sulfate solution (approximately $2,500 \mathrm{~kg} \mathrm{~d}^{-1}$ as pure ammonium sulfate), which is reused as base fertilizer. The top air flow is recirculated to the stripping tower (closed circuit between the stripping and the absorption units). The liquid effluent from the stripping towers is cooled (with heat recovery) and then filtered through sand beds prior to the final $\mathrm{pH}$ neutralization and discharge to the watercourse. Weakly contaminated groundwater $\left(Q=140 \mathrm{~m}^{3} \mathrm{~h}^{-1}\right)$ is fed through this final stage of filtration and neutralization, giving the added benefit of reducing the consumption of the neutralizing acid.

The average performances of the plant with regards to the main pollution parameters are summarized in Table 1. 
Table 1. Summary of the performance of the experimental plant (data reported as mean, $m$, and standard deviation, $s d$, in brackets).

\begin{tabular}{lrrrr}
\hline Parameter & $\begin{array}{c}\text { Raw } \\
\text { groundwater }\end{array}$ & $\begin{array}{c}\text { After } \\
\text { coagulation- } \\
\text { flocculation }\end{array}$ & $\begin{array}{c}\text { After stripping } \\
\text { towers }\end{array}$ & $\begin{array}{c}\text { Final effluent to } \\
\text { river }\end{array}$ \\
\hline $\mathrm{COD}\left[\mathrm{mg} \mathrm{L}^{-1}\right]$ & $370.7(75.5)$ & $180.8(48.9)$ & $150.5(43.3)$ & $77.5(15.3)$ \\
$\mathrm{NH}_{3}\left[\mathrm{mg} \mathrm{L}^{-1}\right]$ & $199.0(101.2)$ & $120.5(43.5)$ & $20.5(8.3)$ & $9.2(3.7)$ \\
$\mathrm{Cl}^{-}\left[\mathrm{mg} \mathrm{L}^{-1}\right]$ & $155.2(25.9)$ & $430.3(52.2)$ & $410.1(51.8)$ & $210.4(32.3)$ \\
$\mathrm{Fe}\left[\mu \mathrm{g} \mathrm{L}^{-1}\right]$ & $350.2(96.7)$ & $85.8(18.8)$ & $55.8(10.2)$ & $17.3(6.8)$ \\
$\mathrm{Ni}\left[\mu \mathrm{g} \mathrm{L}^{-1}\right]$ & $93.0(26.9)$ & $49.6(15.7)$ & $43.5(15.1)$ & $32.1(8.8)$ \\
$\mathrm{Zn}\left[\mu \mathrm{g} \mathrm{L}^{-1}\right]$ & $25.5(14.1)$ & $1.3(8.2)$ & $9.6(3.7)$ & $5.1(2.2)$ \\
\hline
\end{tabular}

\subsection{Research main lines and analytical methods}

The research has been focused on two main aspects:

a. Assessment of the extent and the causes of the scaling phenomenon of the two stripping towers. For this purpose, analytical determinations of hardness (total, calcium, and magnesium) and alkalinity (total, phenolphthalein, as well as the share of total hardness in caustic, bicarbonate and carbonate) were carried out at the six sampling points (Figure 1). For each sampling point, $\mathrm{pH}$ and temperature were also measured and the Langelier Saturation Index (LSI) and the Ryznar Stability Index (RSI) were calculated as indicators of the precipitation potential of the water (Degrémont, 2007). In a period of six months, 35 samples were collected and analyzed for each point.

b. Checking the effects of the scaling on the performance of the stripping towers. For this purpose, the variation in the efficiency of ammonia removal of a single tower was evaluated over a period of six months, during which the initially clean tower progressively reached the highest level of scaling, just before the chemical cleaning. The same efficiency was also evaluated as a function of the liquid rate and the air/liquid ratio, with both the clean and scaled towers.

Average daily values, standard deviations and minimum-maximum range were obtained and shown in the illustrative graphs of the various analyzed parameters.

Official standard methods for the Examination of Water and Wastewater were adopted for sampling and analysis (Clesceri et al., 1998).

Temperature and $\mathrm{pH}$ were measured continuously with fixed probes $( \pm 0.1$ accuracy for $\mathrm{T}$ and \pm 0.05 accuracy for $\mathrm{pH}$ ).

\section{RESULTS AND DISCUSSION}

\subsection{Extent and causes of scaling}

Figure 2 shows the water hardness in the six sampling points of the treatment plant.

First of all, it can be observed that in the raw water the calcium hardness was dominant ( $81 \%$ of the total). In the initial stage of the coagulation-flocculation process a high reduction of the total hardness $(90 \%)$ was achieved, due to the precipitation at $\mathrm{pH}>11.0$ of $\mathrm{CaCO}_{3}$ and $\mathrm{Mg}(\mathrm{OH})_{2}$ according to the following reactions (1), (2) and (3):

$$
\begin{aligned}
& \mathrm{Ca}\left(\mathrm{HCO}_{3}\right)_{2}+2 \mathrm{NaOH} \rightarrow \mathbf{C a C O}_{3}+\mathrm{Na}_{2} \mathrm{CO}_{3}+2 \mathrm{H}_{2} \mathrm{O} \\
& \mathrm{Mg}\left(\mathrm{HCO}_{3}\right)_{2}+4 \mathrm{NaOH} \rightarrow \mathbf{M g}(\mathbf{O H})_{2}+2 \mathrm{Na}_{2} \mathrm{CO}_{3}+2 \mathrm{H}_{2} \mathrm{O} \\
& \mathrm{MgCl}_{2}+2 \mathrm{NaOH} \rightarrow \mathbf{M g}(\mathbf{O H})_{2}+2 \mathrm{NaCl}
\end{aligned}
$$




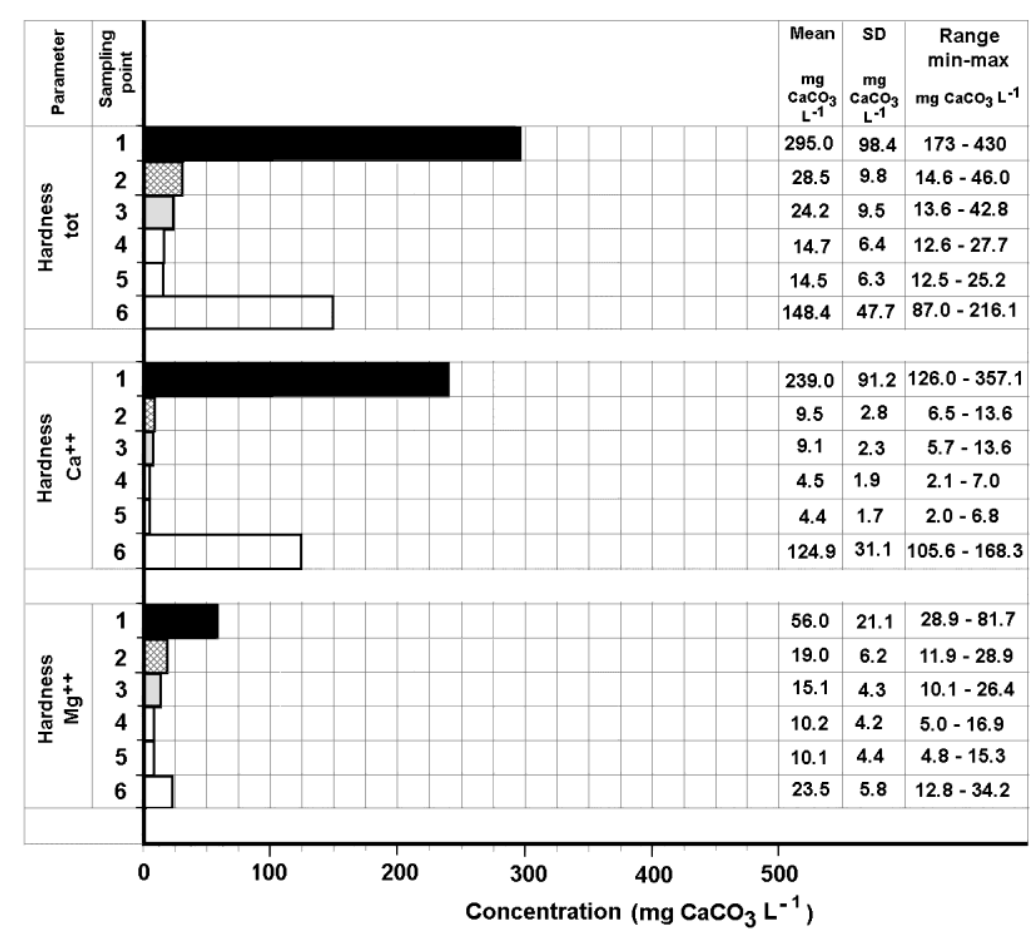

Figure 2. Water hardness, as total, calcium and magnesium, in the six sampling points (data as mean, standard deviation and range min-max).

Despite this drastic hardness reduction a further precipitation, within the plates heat exchanger HE1 and especially over the packing of the stripping towers has been observed. This is due to the heating of the water (to $38^{\circ} \mathrm{C}$ ) and to the high water alkalinity, essentially caustic and carbonate as a consequence of the high water $\mathrm{pH}$ (Figure 3 ).

Indeed, the increase in temperature causes a lowering of the solubility product $K_{s p}$ of precipitates (for $\mathrm{CaCO}_{3}: K_{s p}=3.2933 \cdot 10^{-9} \mathrm{~mol}^{2} \mathrm{~L}^{-2}$ at $25^{\circ} \mathrm{C}$, while $K_{s p}=2.670810^{9} \mathrm{~mol}^{2} \mathrm{~L}^{-2}$ at $38^{\circ} \mathrm{C}$ ) (Green and Perry, 2007; Lide, 2004), and the high alkalinity favors the achievement of the same $K_{s p}$ level (despite the small concentration of the residual hardness).

In the graph of Figure 2 it can be observed that the precipitation of the residual hardness started in the plate heat exchanger HE1 and was completed inside the stripping towers. However, a further effect of post-precipitation, though much smaller, was also found in the heat exchanger HE2 downstream of the stripping towers and in the subsequent centrifuge pumps feeding the water to the final stage of sand filtration and neutralization. This result was observed despite the lowering of both water temperature to $25.2^{\circ} \mathrm{C}$ and $\mathrm{pH}$ to 10.67 in the output of the stripping towers. Total hardness increased in the final effluent, simply due to the mixing with the weakly contaminated groundwater.

The precipitation of calcium carbonate is governed by the following equilibria (4), (5) and (6):

$$
\begin{array}{lr}
\mathrm{Ca}^{2+}+\mathrm{CO}_{3}{ }^{2-} \rightleftarrows \mathrm{CaCO}_{3(\mathrm{l})} \rightleftarrows \mathrm{CaCO}_{3(\mathrm{~s})} & K_{s p}=\left[\mathrm{Ca}^{2+}\right] \cdot\left[\mathrm{CO}_{3}{ }^{2-}\right] \\
\mathrm{CO}_{3}{ }^{2-}+\mathrm{H}^{+} \rightleftarrows \mathrm{HCO}_{3}^{-} & K_{a 2}=\frac{\left[\mathrm{CO}_{3}{ }^{2-}\right] \cdot\left[\mathrm{H}^{+}\right]}{\left[\mathrm{HCO}_{3}{ }^{-}\right]} \\
\mathrm{HCO}_{3}{ }^{-}+\mathrm{H}^{+} \rightleftarrows \mathrm{H}_{2} \mathrm{CO}_{3} & K_{a 1}=\frac{\left[\mathrm{HCO}_{3}^{-}\right] \cdot\left[\mathrm{H}^{+}\right]}{\left[\mathrm{H}_{2} \mathrm{CO}_{3}\right]}
\end{array}
$$


where:

$K_{a 1}$ and $K_{a 2}$ are the equilibrium constants.

Combining the three equations, the following correlation between the solubility of $\mathrm{Ca}^{2+}$ and the hydrogen ion concentration (and consequently the water $\mathrm{pH}$ ) is obtained (7):

$$
\left[\mathrm{Ca}^{2+}\right]^{2}=K_{s p} \cdot\left(1+\frac{\left[\mathrm{H}^{+}\right]}{K_{a 2}}+\frac{\left[\mathrm{H}^{+}\right]^{2}}{K_{a 2} \cdot K_{a 1}}\right)
$$

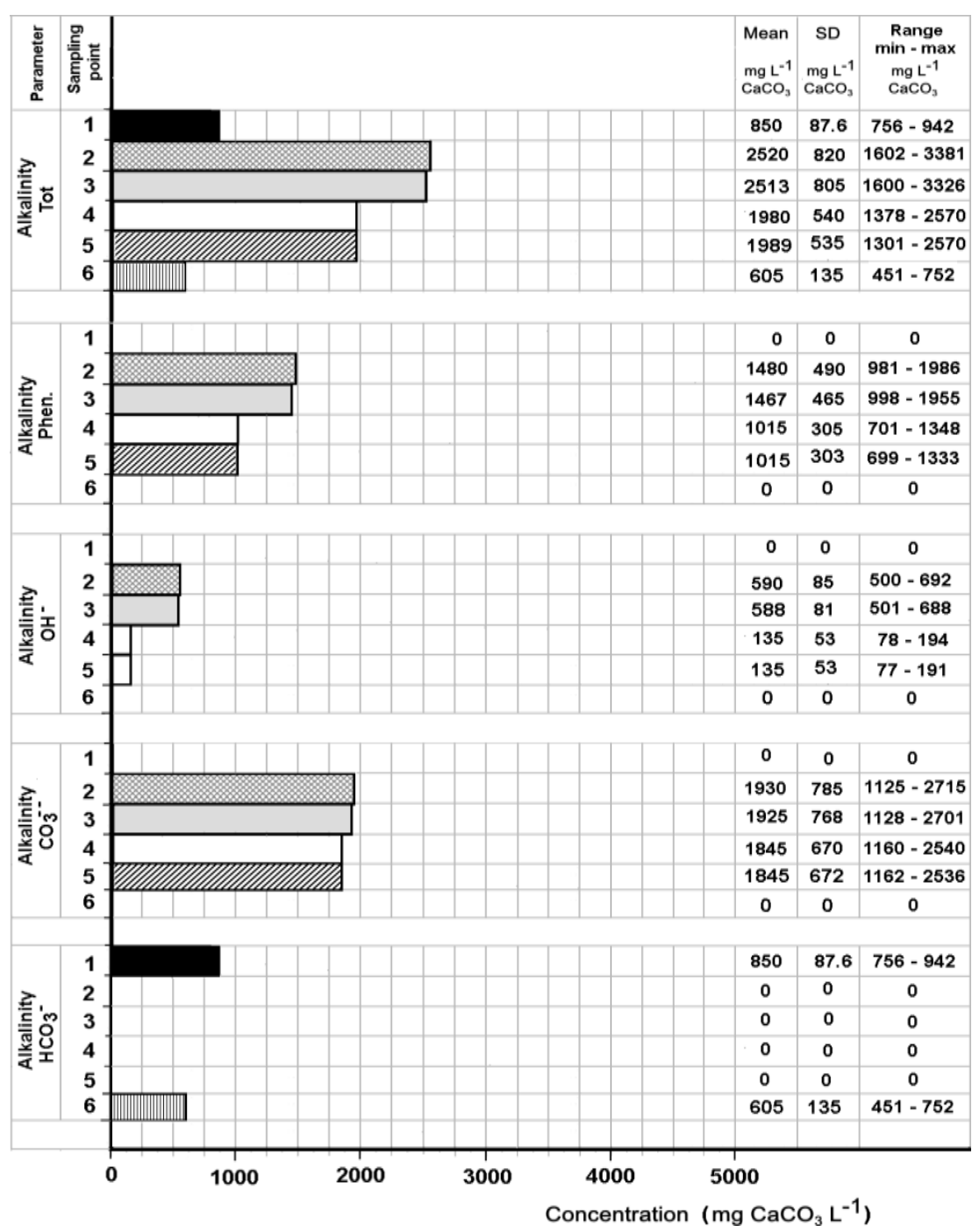

Figure 3. Alkalinity values (total, phenolphtaleine, caustic, carbonate, bicarbonate) at the six sampling points (data as mean, standard deviation and range min-max).

The level of scaling reached in the plates heat exchanger HE1 has imposed periodic chemical washings with hydrochloric acid solutions. The same kind of washing was necessary for the removal of the even heavier scaling of the packing of the stripping towers (periodicity of chemical washing of about six months). This scaling has mostly affected the upper area of the packing because of three factors: higher concentrations of hardness and alkalinity in the water at the top of the stripping tower; higher temperature $\left(38^{\circ} \mathrm{C}\right.$, compared with the outlet, 25.2 $\left.{ }^{\circ} \mathrm{C}\right)$; higher $\mathrm{pH}$ (11.3, compared with the outlet, 10.67). 
The variation of the temperature profile along the stripping tower is determined by the cooling induced by the stripping air coming from the absorption tower (closed-loop recirculation of the air). This air has an acidic character and therefore influences the vertical $\mathrm{pH}$ profile along the tower. The trend of $\mathrm{pH}$ and temperature in the six sampling points of the plant is shown in the graph of Figure 4.

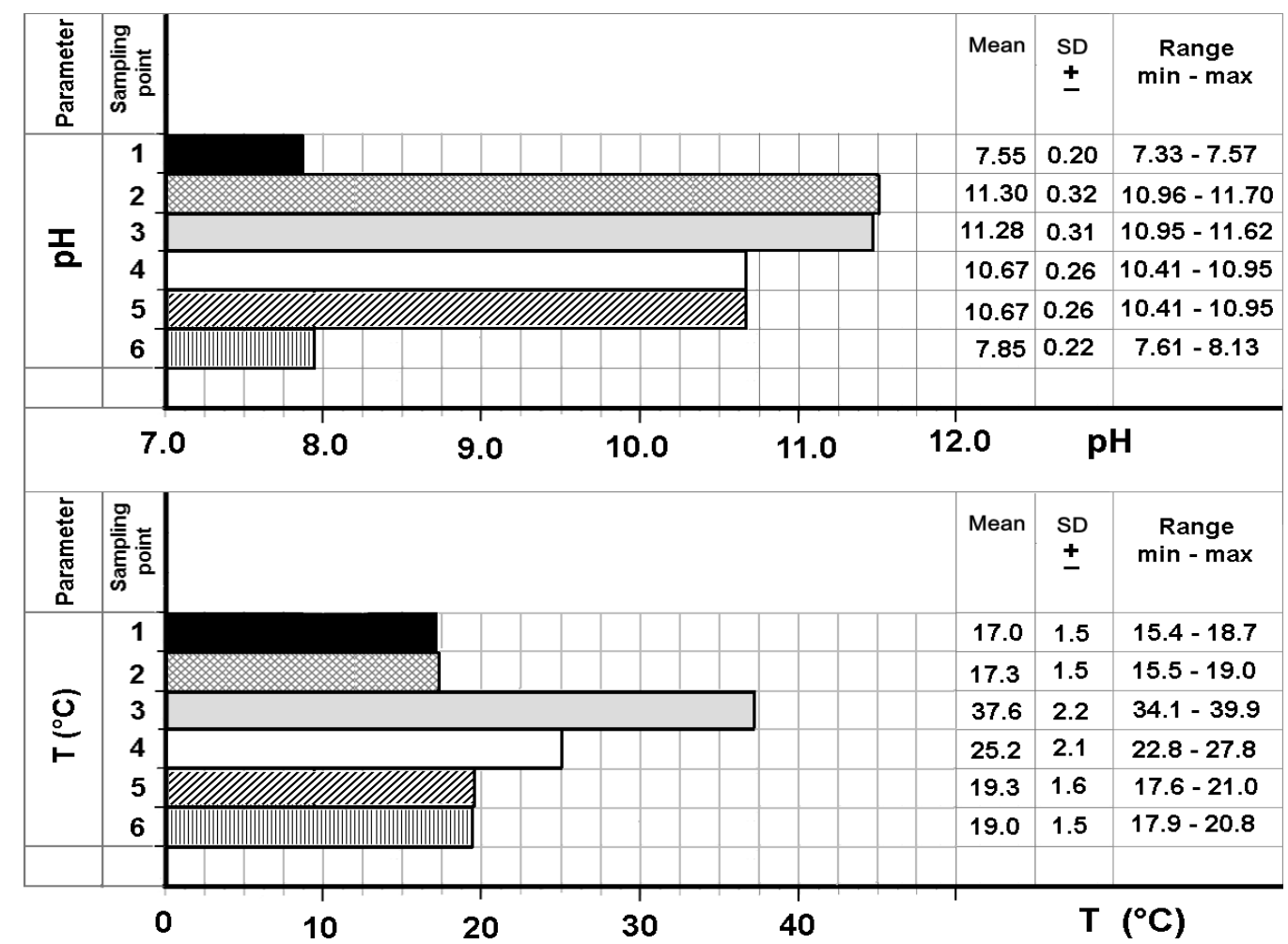

Figure 4. $\mathrm{pH}$ and temperature at the six sampling points (data as mean, standard deviation and range min-max).

The progressive scaling of the packing resulted in an increase of the weight of the single Pall rings up to seven fold the original weight (clean Pall rings) and in a relevant reduction of the interfacial surface area (over $40 \%$ ).

In order to assess the potential scaling of the water, the LSI and the RSI were calculated for the six sampling points (Figure 5).

The LSI, traditionally used for this type of evaluation, is represented by the following expression (8):

$$
L S I=p H-p H_{s}=p H-\left[\left(p K_{a 2}-p K_{s p}\right)+p C a^{2+}+p A l k\right]
$$

where:

$p H$ is the real $\mathrm{pH}$ of the water and

$\mathrm{pH}_{\mathrm{S}}$ is the saturation $\mathrm{pH}$.

$L S I<0$ indicates aggressive water, while $L S I>0$ indicates a scaling character of the water.

As $p H_{s}$ contains a dependence from both the salinity of the water and temperature (dependence in the constants $K_{a 2}$ and $K_{s p}$ ) the $L S I$ was easier calculated by using the Langelier-Hoover abacus (Degrémont, 2007).

The RSI, which has always positive values, is defined by the following expression (9):

$$
R S I=2 \cdot p H_{s}-p H
$$

Rev. Ambient. Água vol. 10 n. 2 Taubaté - Apr. / Jun. 2015 
Although less used due to its empirical character, the RSI has the advantage of being well correlated with the water's tendency to form scale or to be aggressive, as follows:

$$
\begin{aligned}
& R S I=4-5-\text { high scaling } \\
& R S I=5-6-\text { scaling } \\
& R S I=6-7-\text { weak scaling } \\
& R S I=7-8-\text { aggressive } \\
& R S I=8-9-\text { very aggressive } \\
& R S I>9-\text { strongly aggressive }
\end{aligned}
$$

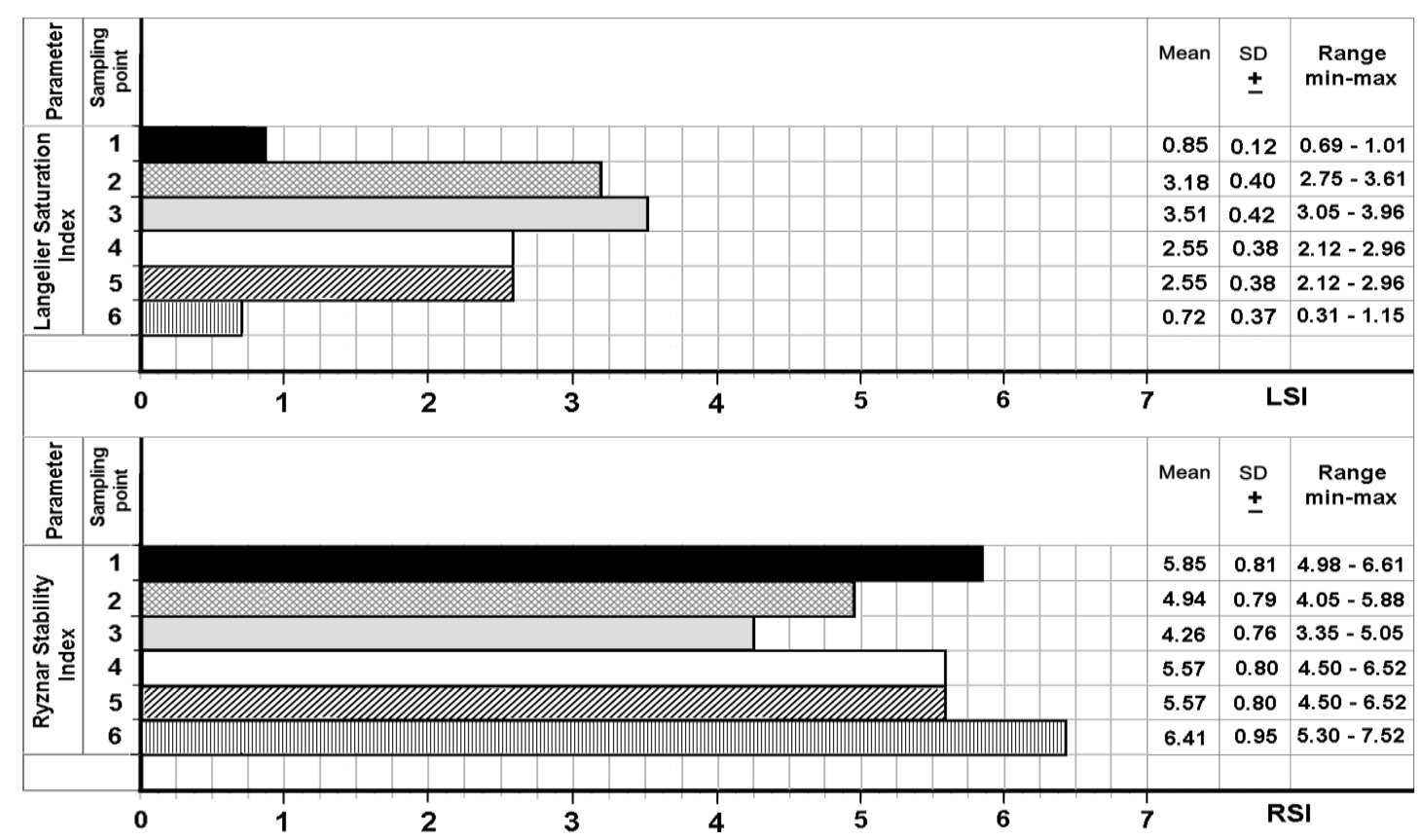

Figure 5. Values of the Langelier Saturation Index and Ryznar Stability Index calculated for the six sampling points (data as mean, standard deviation and range min-max).

The values calculated for both these indices prove the "high scaling" potential of the water fed into the stripping tower $(L S I=3.51$ and $R S I=4.26$, as mean) and only "scaling" for the outlet water $(L S I=2.55$ and $R S I=5.57$, as mean), confirming the highlighted effects of scaling along the plant. Only the final effluent downstream of the neutralization regains values of the indexes close to equilibrium $(L S I=0.72$ and $R S I=6.41$, as mean).

\subsection{Effects of the scaling on the stripping performance}

Figure 6 shows the evolution of ammonia removal efficiency of the stripping towers during six months of continuous operation with a liquid rate of $2.1 \mathrm{~m}^{3} \mathrm{~h}^{-1} \mathrm{~m}^{-2}$ and an air/water ratio of $2,400 \mathrm{Nm}^{3} \mathrm{~m}^{-3}$.

The efficiency undergoes a progressive reduction from the initial value of $98 \%$ (clean packing) down to the value of $80 \%$, at which the tower has been subjected to chemical cleaning to remove the scaling. The curve has an increasing gradient due to the fact that the progressive scaling determines not only a reduction of the interfacial surface area of packing, but also determines an increase of the head losses with consequent gradual reduction of the air flow, and then the air /liquid ratio. 


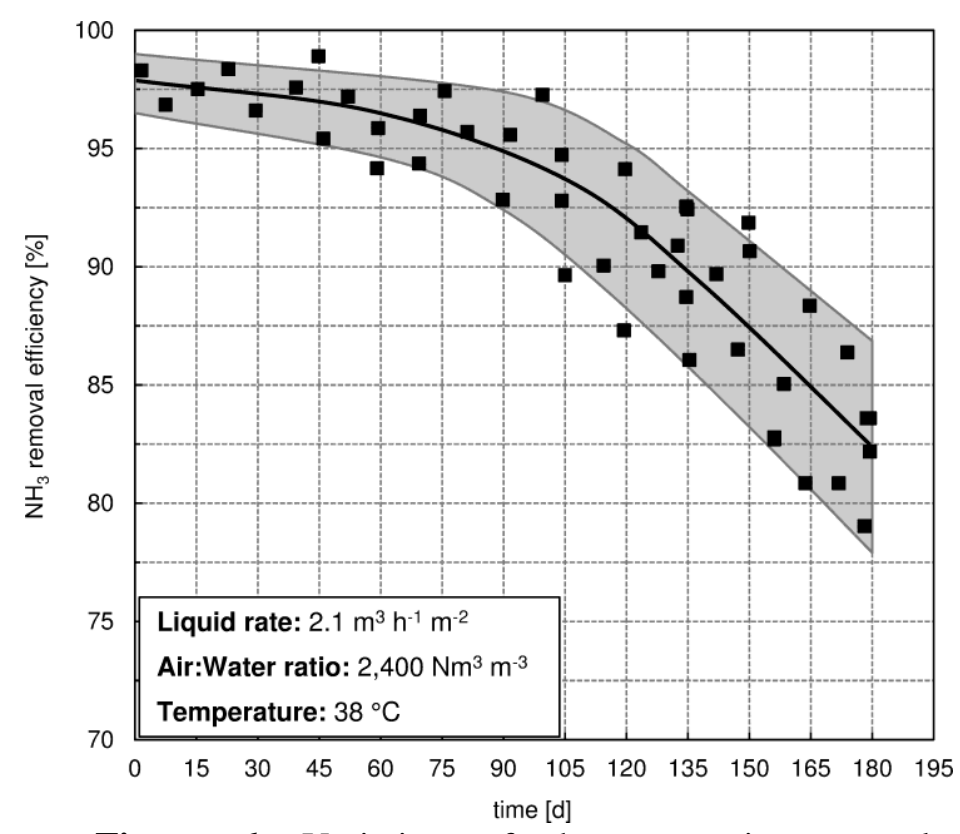

Figure 6. Variation of the ammonia removal efficiency during six months of continuous operation, showing the effect of the progressive scaling (mean value and $95 \%$ interval of confidence).

Figure 7 shows the efficiency of ammonia stripping as a function of the liquid rate, as regards the clean towers (at $38^{\circ} \mathrm{C}$ and $32^{\circ} \mathrm{C}$ ) and the towers at the highest level of scaling (at $38^{\circ} \mathrm{C}$ ).

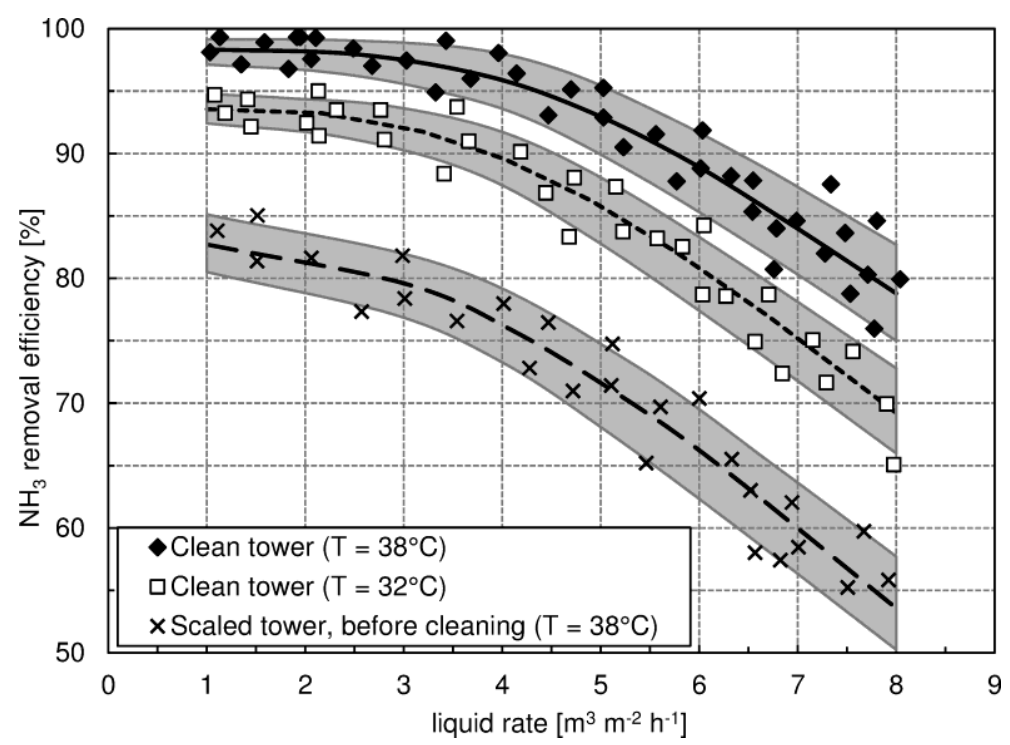

Figure 7. Ammonia removal efficiency as a function of the liquid rate in clean stripping tower (at $38^{\circ} \mathrm{C}$ and $32^{\circ} \mathrm{C}$ ) and in stripping tower at the highest level of scaling $\left(38^{\circ} \mathrm{C}\right)$.

The comparison of the curves allows an immediate assessment of the impact of the temperature and scaling on the ammonia removal efficiency.

Figure 8 shows the same efficiency as a function of the air/liquid ratio, always with reference to clean towers and towers at the highest level of scaling. 


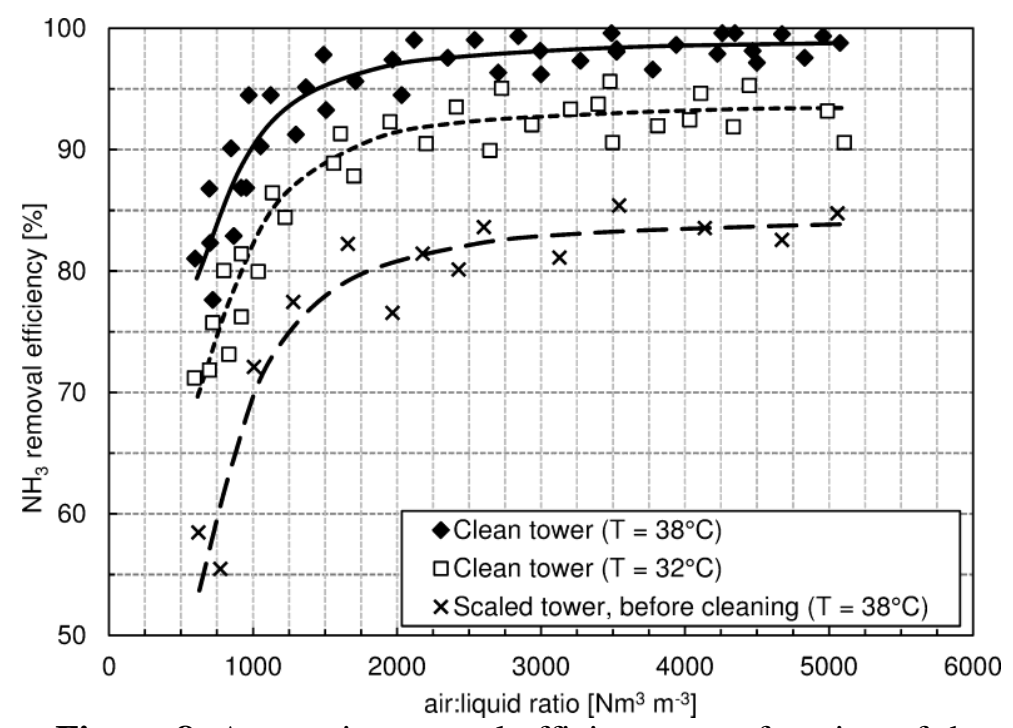

Figure 8. Ammonia removal efficiency as a function of the air/liquid ratio in clean stripping tower (at $38^{\circ} \mathrm{C}$ and $32^{\circ} \mathrm{C}$ ) and in stripping tower at the highest level of scaling $\left(38^{\circ} \mathrm{C}\right)$.

The observation of the curves in Figures 7 and 8 highlights the following points:

- for the achievement of high ammonia removal efficiencies (higher than 95\%) it is necessary to operate with liquid rates below $4.5 \mathrm{~m}^{3} \mathrm{~m}^{-2} \mathrm{~h}^{-1}$ and with air/liquid ratios over $1,500 \mathrm{Nm}^{3} \mathrm{~m}^{-3}$ (at $38^{\circ} \mathrm{C}$ );

- due to the problem of scaling, a highly efficient stripping continuous process is achievable only with two or more parallel stripping towers in order to cope with the progressive loss of efficiency of the scaled towers and the off-service periods for the chemical washing.

\section{CONCLUSIONS}

The physical-chemical process studied, consisting of coagulation-flocculation at $\mathrm{pH}>11$ followed by the water heating at $38^{\circ} \mathrm{C}$ and ammonia stripping (with subsequent recovery of ammonia by absorption with a sulfuric acid solution) showed severe scaling issues (mainly limestone) over the stripping towers packing, with an increase in weight of the single components (Pall rings) up to seven times the original weight. The scaling has mostly affected the upper zone of the tower because of three factors: higher concentrations of hardness and alkalinity in the water at the top of the stripping tower; inlet water temperature higher than the outlet one $\left(38^{\circ} \mathrm{C}\right.$ respect to $\left.25.2^{\circ} \mathrm{C}\right)$; and inlet water $\mathrm{pH}$ higher than the outlet one (11.28 respect to 10.67). The temperature profile along the tower was determined by the cooling action of the stripping air coming from the ammonia absorption towers (closed-loop air recirculation), while $\mathrm{pH}$ profile was influenced by the acid character of the air recirculated to the stripping towers.

The scaling effects were well highlighted by the Langelier and Ryznar saturation indexes.

The progressive scaling produced an $18 \%$ loss in ammonia removal efficiency (from $98 \%$ to $80 \%$ ) caused by the reduction of both the packing interfacial surface (up to $40 \%$ ) and the air/water ratio (due to the increase in head losses). As a consequence of the scale build-up, a periodic (every six months) chemical washing of the stripping towers with a $30 \%$ hydrochloric acid solution was carried out.

The results of this study demonstrate the real possibility of achieving high ammonia removal efficiencies (higher than 95\%) operating the stripping towers at $38^{\circ} \mathrm{C}$ with liquid 
rates below $4.5 \mathrm{~m}^{3} \mathrm{~m}^{-2} \mathrm{~h}^{-1}$ and air/water ratios above $1,500 \mathrm{Nm}^{3} \mathrm{~m}^{-3}$. However, a highly efficient continuous process is achievable only with two or more parallel stripping towers in order to cope with the progressive loss of efficiency (due to scale build-up) and the off-service periods for chemical washing.

\section{REFERENCES}

CAMPOS, J. C.; MOURA, D.; COSTA, A. P.; YOKOYAMA, L; ARAUJO, F. V. D. F; CAMMAROTA, M. C. Evaluation of $\mathrm{pH}$, alkalinity and temperature during air stripping process for ammonia removal from landfill leachate. Journal of Environmental Science and Health - Part A Toxic/Hazardous Substances and Environmental Engineering, v. 48, n.9, p. 1105-1113, 2013. http://dx.doi.org/10.1080/10934529.2013.774658

CLESCERI, L. S.; GREENBERG, A. E.; EATON, A. D. Standard methods for the examination of water and wastewater. $20^{\text {th }}$ ed. Washington DC: APHA, 1998.

COPELli, S.; TORRETTA, V.; RABONI, M.; VIOTTI, P.; LUCIANO, A.; MANCINI, G. Improving biotreatment efficiency of hot waste air streams: Experimental upgrade of a full plant. Chemical Engineering Transactions, v. 30, p. 49-54, 2012. http://dx.doi.org/10.3303/CET1230009

DEGRÉMONT. Water treatment handbook. $7^{\text {th }}$ ed. Degrémont, 2007.

ERAMO, B.; GAVASCI, R.; MISITI, A.; VIOTTI, P. Validation of a multisubstrate mathematical model for the simulation of the denitrification process in fluidized bed biofilm reactors. Water Science and Technology, v. 29, n. 10-11, p. 401-408, 1994.

FARABEGOLI, G.; GAVASCI, R.; LOMBARDI, F.; ROMANI, F. Denitrification in tertiary filtration: Application of an up-flow filter. Journal of Environmental Science and Health - Part A Toxic/Hazardous Substances and Environmental Engineering, v. 38, n. 10, p. 2169-2177, 2003. http://dx.doi.org/10.1081/ESE-120023349

FERRAZ, F. M.; POVINELLI, J.; VIEIRA, E. M. Ammonia removal from landfill leachate by air stripping and absorption. Environmental Technology, v. 34, n. 15, p. 23172326, 2013. http://dx.doi.org/10.1080/09593330.2013.767283

GREEN, D.; PERRY, R. Perry's chemical engineers' handbook. $8^{\text {th }}$ ed. New York: McGraw-Hill Education, 2007.

LIDE, D. R. CRC handbook of chemistry and physics. $85^{\text {th }}$ ed. Boca Raton: CRC Press; Taylor \& Francis, 2004.

RABONI, M.; GAVASCI, R.; URBINI, G. UASB followed by sub-surface horizontal flow phytodepuration for the treatment of the sewage generated by a small rural community. Sustainability, v. 6, n. 10, p. 6998-7012, 2014a. http://dx.doi.org/10.3390/su6106998

RABONI, M.; TORRETTA, V.; URBINI, G. Influence of strong diurnal variations in sewage quality on the performance of biological denitrification in small community wastewater treatment plants (WWTPs). Sustainability, v. 5, n. 9, p. 3679-3689, $2013 \mathrm{a}$. http://dx.doi.org/10.3390/su5093679 
RABONI, M.; TORRETTA, V.; URBINI, G.; VIOTTI, P. Automotive shredder residue: a survey of the hazardous organic micro-pollutants spectrum in landfill biogas. Waste

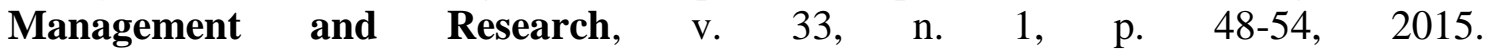
http://dx.doi.org/10.1177/0734242X14559300

RABONI, M.; TORRETTA, V.; VIOTTI, P.; URBINI, G. Experimental plant for the physical-chemical treatment of groundwater polluted by municipal solid waste (MSW) leachate, with ammonia recovery. Revista Ambiente \& Agua, v. 8, n. 3, p. 22-32, 2013b. http://dx.doi.org/10.4136/ambi-agua. 1250

RABONI, M.; TORRETTA, V.; VIOTTI, P.; URBINI, G. Calculating specific denitrification rates in pre-denitrification by assessing the influence of dissolved oxygen, sludge loading and mixed-liquor recycle. Environmental Technology, v. 35, n. 20, p. 25822588, 2014b. http://dx.doi.org10.1080/09593330.2014.913690

RABONI, M.; TORRETTA, V.; VIOTTI, P.; URBINI, G. Pilot experimentation with complete mixing anoxic reactors to improve sewage denitrification in treatment plants in small communities. Sustainability, v. 6, n. 1, p. 112-122, 2014c. http://dx.doi.org/10.3390/su6010112

RADA, E. C.; RABONI, M.; TORRETTA, V.; COPELLI, S.; RAGAZZI, M., CARUSON, P. Removal of benzene from oil refinery wastewater treatment plant exchausted gases with a multi-stage biofiltration pilot plant. Revista de Chimie, v. 65, n. 1, p. 68-70, 2014a.

RADA, E.C.; RAGAZZI, M.; IONESCU, G.; MERLER, G.; MOEDINGER, F.; RABONI, M. Municipal solid waste treatment by integrated solutions: energy and environmental $\begin{array}{lllll}\text { balances. } & \text { Energy } & \text { Procedia, v. 50, p.1037-1044, }\end{array}$ http://dx.doi.org/10.1016/j.egypro.2014.06.123

REGADÍO, M.; RUIZ, A. I.; DE SOTO, I. S.; RODRIGUEZ RASTRERO, M.; SÁNCHEZ, N.; GISMERA, M. J. Pollution profiles and physicochemical parameters in old uncontrolled landfills. Waste Management, v. 32, n. 3, p. 482-497, 2012. http://dx.doi.org/10.1016/j.wasman.2011.11.008

RENOU, S.; GIVAUDAN, J. G.; POULAIN, S.; DIRASSOUYAN, F.; MOULIN, P. Landfill leachate treatment: review and opportunity. Journal of Hazardous Materials, v. 150, n. 3, p. 468-493, 2008. http://dx.doi.org/10.1016/j.jhazmat.2007.09.077

SUN, G.; ZHU, Y.; SAEED, T.; ZHANG, G.; LU, X. Nitrogen removal and microbial community profiles in six wetland columns receiving high ammonia load. Chemical Engineering Journal, v. 203, p. 326-332, 2012. http://dx.doi.org/ 10.1016/j.cej.2012.07.052

TORRETTA, V.; IONESCU, G.; RABONI, M.; MERLER, G. The mass and energy balance of an integrated solution for municipal solid waste treatment. In: INTERNATIONAL CONFERENCE ON WASTE MANAGEMENT AND THE ENVIRONMENT, 7., 1214 May 2014, Ancona, Italy. WIT Transactions on Ecology and the Environment, v. 180, p. 151-161, 2014a. http://dx.doi.org/10.2495/WM140131 
TORRETTA, V.; RABONI, M.; COPELLI, S.; CARUSON, P. Application of multi-stage biofilter pilot plants to remove odor and VOCs from industrial activities air emissions. In: INTERNATIONAL CONFERENCE ON ENERGY AND SUSTAINABILITY, 4. 19-21 Jun 2013, Bucharest, Romania. WIT Transactions on Ecology and the Environment, v. 176, p. 225-233, 2013a. http://dx.doi.org/102495/ESUS130191

TORRETTA, V.; URBINI, G.; RABONI, M.; COPELLI, S.; VIOTTI, P.; LUCIANO, A. Effect of powdered activated carbon to reduce fouling in membrane bioreactors: a sustainable solution. Case study. Sustainability, v. 5, n. 4, p. 1501-1509, 2013b. http://dx.doi.org/10.3390/su5041501

YILMAZ, T.; AYGÜN, A.; BERKTAY, A.; NAS, B. Removal of COD and colour from young municipal landfill leachate by Fenton process. Environmental Technology, v. 31, n. 14, p. 1635-1640, 2010. http://dx.doi.org/10.1080/09593330.2010.494692 